\title{
EXCHANGE RATE REGIMES AND MACROECONOMIC STABILITY IN CENTRAL AND EASTERN EUROPE
}

\author{
PAUL De GRAUWE \\ GUNTHER SCHNABL
}

CESIFO WORKING PAPER NO. 1182

CATEgORY 6: MONETARY POLICY AND INTERNATIONAL FINANCE

APRIL 2004

- from the CESifo website:

www.CESifo.de 


\title{
EXCHANGE RATE REGIMES AND MACROECONOMIC STABILITY IN CENTRAL AND EASTERN EUROPE
}

\begin{abstract}
This paper explores the impact of the exchange rate regime on inflation and output in the Central and Eastern European (CEE) EU candidate countries. The panel estimations for the period between 1994 and 2002 show that de facto measures of exchange rate stability have a better explanatory power than the de jure measures in the inflation and growth equations. For the whole observation period the estimations reveal a significant impact of exchange rate stability on low inflation as well as a highly significant positive impact of exchange stability on real growth. When sub-dividing the period into a "high-inflation" period (1994-1997) and a "low-inflation period" (1998-2002) and when removing outliers from the sample, the evidence in favour of a positive association between exchange rate stability and inflation gets weaker. The association of exchange rate stability with higher real growth remains quite robust. Thus our findings can be interpreted to mean that membership of the CEE countries in the European Monetary Union would have a positive impact on these countries' growth rates.
\end{abstract}

JEL classification: F31.

Keywords: exchange rate regimes, inflation, growth, Central and Eastern Europe, macroeconomic stability.

Paul De Grauwe

Katholieke Universiteit Leuven

Center for Economic Studies

Naamsestraat 69

3000 Leuven

Belgium

paul.degrauwe@econ.kuleuen.ac.be
Gunther Schnabl

Tübingen University

Dept of Economics and Business

Administration

Nauklerstrasse 47

72074 Tübingen

Germany

gunther.schnabl@uni-tuebingen.de

We thank Christian Arndt, Mike Artis, Boštjan Jazbec, Sebastian Moll and Laura Rinaldi for helpful comments. 


\section{Introduction}

In the very near future eight Central and Eastern European (CEE) countries will join the European Union (EU). Bulgaria and Romania are expected to follow by 2007. The eastern enlargement of the European Union heralds the enlargement of the European Monetary Union (EMU). Within a few years the EMU could grow to a size of up to 25 member states.

The possible enlargement of the European Monetary Union raises the question of its costs and benefits. Is the EU25 an optimum currency area? The traditional theoretical framework of optimum currency areas (OCA) as developed by Mundell (1961) — henceforth Mundell I-leads to scepticism. As heterogeneity will increase within the EMU25, the probability of asymmetric shocks will rise. In the perspective of Mundell I one may come to the conclusion that it is not in the interest of the enlarged EU to embark on a monetary union.

Nevertheless, several CEE countries have expressed their strong intention to join the EMU as soon as possible (Backé and Thimann 2004). The rationale in favour of an early EMU membership is to be found outside the traditional OCA framework. As stressed in some of Mundell's (1973a and 1973b) later papers, in a world of non-stationary expectations, exchange rate movements do not function as stabilizing instruments in the face asymmetric shocks. Instead they are likely to be an independent source of volatility. In this view, which we label Mundell II, an early EMU membership could be the optimal choice.

Which framework applies for the CEE countries? Mundell I or Mundell II? Should the CEE countries maintain their monetary independence as long as possible to cope with asymmetric shocks during their economic catch-up process? Or should they join the EMU quickly to reap the benefits of irrevocably fixed exchange rates?

This paper adds to this discussion by measuring the impact of exchange rate stability on inflation and output growth in the CEE countries. If fixed exchange rates contribute to low inflation and high growth, EMU enlargement could be seen as providing a source of benefits for its prospective members. We will use a panel data approach to perform this analysis.

\section{Costs and Benefits of Entering the Eurozone: Mundell I versus Mundell II}

The decision of the new CEE member states when to enter the European Monetary Union will depend on the perceived costs and benefits. The traditional theory of optimum currency areas as put forward by Mundell (1961) and McKinnon (1963) has relied on three criteria to make an assessment about the costs and benefits of a monetary union: asymmetry, flexibility and openness (integration). 
The seminal paper by Mundell (1961) on optimum currency areas focused on asymmetric shocks and flexibility of labour markets. Assuming sticky prices and wages, Mundell analysed the macroeconomic adjustment mechanisms of demand shifts between regions (countries). Within this Keynesian framework, Mundell concluded that countries which face large asymmetric would find it costly to loose their monetary and exchange rate policies when entering a monetary union. These costs, however, would be reduced if these countries were characterised by wage flexibility and labour mobility.

The analysis presented by Mundell (1961) led to scepticism about the desirability of forming a monetary union among countries, which experience large asymmetric shocks and lack labour market flexibility. We represent this Mundell I analysis in the left panel of Figure $1 .{ }^{1}$ On the vertical axis we set out the degree of asymmetry of shocks among clusters of countries; on the vertical axis we present the degree of flexibility of the labour markets in these countries. The OCA line represents the combinations of asymmetry and flexibility for which the costs of a monetary union equal the benefits. This is a positively sloped line because an increase in asymmetry increases the costs of a monetary union. As a result, in order to keep the costs equal to the benefits, flexibility must increase. When countries are located to the right of the OCA-line the benefits of the union exceed the costs. These countries form an optimal currency area. The opposite holds when countries are located to the left of the OCA-line.

McKinnon (1963) introduced the degree of openness as an additional variable affecting the costs and benefits of a monetary union. More particularly it can be shown that as the degree of openness, increases the benefits of a monetary union also increase. These benefits arise from the fact that the elimination of exchange rate variability reduces transactions costs and the volatility of domestic prices. These beneficial effects are likely to increase with the degree of openness of countries.

The right panel of Figure 1 analyses the costs and benefits of a monetary union based on these insights. We set the degree of openness of countries on the horizontal axis. The OCA-line gives the combinations of asymmetry and openness for which the costs and the benefits of a monetary union are equal. It is positively sloped because when asymmetry increases (which raises the costs) one needs an increase in openness (which raises the benefits) to keep costs and benefits in balance. Countries on the right hand side of the OCA-line will find it beneficial to be in a monetary union. They form an optimal currency area.

Where should be located the EMU25-which would include all EU accession countries as well as the present "outs" Denmark, Sweden and UK - in Figure 1? The empirical evidence is most

\footnotetext{
${ }^{1}$ For more detail about this graphical representation see De Grauwe (2003).
} 
clear-cut for openness. Figure 2 shows the exports to the EU15 as percent of GDP for four groups of countries: the twelve present EMU members, the three EMU "outs", the ten CEE potential EMU member states (including Romania and Bulgaria) as well as Cyprus and Malta.

In the year 2002 trade to the EU15 as percentage of GDP was higher for the CEE countries than for the present EMU members. ${ }^{2}$ Exports to the EU as percentage of GDP averaged 26.6\% for the CEE countries in comparison with $20.9 \%$ for the EMU member states. Trade integration with the EU15 is stronger for the CEE countries than for the EMU "outs" Denmark, Sweden and UK (13.3\% on average). Thus, based on McKinnon's (1961) openness criterion the Central and Eastern European countries seem to pass the OCA-test.

The degree of asymmetric shocks is more difficult to quantify. More than a decade ago, Bayoumi and Eichengreen (1993) used a VAR methodology as proposed by Blanchard and Quah (1989), to measure asymmetric shocks in the potential first wave of EMU member states. Based on the assumption that demand shocks are temporary and supply shocks are persistent Bayoumi and Eichengreen (1993: 221-222) concluded that " a strong distinction emerges between supply shocks affecting the countries at the centre of the European Community-Germany, France, Belgium, the Netherlands and Denmark - and the very different supply shocks affecting other EC members-the United Kingdom, Italy, Spain, Portugal, Ireland and Greece."

What is the evidence about the degree of asymmetry in the group of countries comprising the Central and Eastern European countries? Buiter and Grafe (2002) who analyse the heterogeneity of national incomes structures and co-movements of inventory cycles find evidence that CEE business cycles are by no means being synchronized with the EU15. Fidrmuc and Korhonen (2002) use the VAR framework by Blanchard and Quah (1989) to show that for the most accession countries the shocks are significantly more idiosyncratic with regard to the EU25 than for the EU15.

Least is known about the flexibility of labour markets in the EU25. Riboud, SánchezPáramo and Silva-Jáuregui (2002) analyse labour market flexibility in six CEE countries during the 1990s. They conclude that in comparison to the other OECD countries the CEE countries (in average) range in the middle, exhibiting more flexibility than France or Germany but less than the United States and the United Kingdom. A panel study by Alvarez-Plata, Brückner and Siliverstovs (2003) of the potential migration from Central and Eastern Europe into the EU15 predicts considerable movement of labour force from the CEE countries into Germany and other EU15 countries.

2 Membership in a currency union is expected to increase trade integration among the members (Frankel and Rose 1998). Micco, Stein and Ordoñez (2003) argue that EMU membership has increased bilateral trade between the present members considerably compared with trade with the non-EMU countries. 
All in all, the empirical evidence seems to be mixed. Trade integration of the CEE countries with the rest of the union well advances. However, the degree of asymmetry of shocks appears to be relatively high, while flexibility is not particularly strong. All this suggests that is not unreasonable to conclude that the EU25 would not at this moment constitute an optimal currency area. On the basis of this analysis, the Deutsche Bundesbank (2003: 19) concluded that a high degree of exchange rate flexibility might be the better choice for the CEE countries thereby suggesting a "careful timing" of EMU accession. In this view, the CEE countries would be well advised to postpone EMU membership — at least if the traditional OCA criteria are considered.

The previous analysis was based on what we have labelled Mundell I, which is a very Keynesian framework assuming fixed prices and wages. The view we have from the later work of Mundell (1973a and 1973b) which we labelled Mundell II is very different (McKinnon 2003). In Mundell II exchange rate movements do not play the role of stabilizing the economy in the face of asymmetric shocks. Instead, these exchange rate movements are independent sources of volatility. The reason is that foreign exchange markets are not efficient. They are dominated by a speculative dynamics that lead to exchange rate movements unconnected from movements in the fundamentals.

As a result, exchange rates exhibit excess volatility and are a source of great macroeconomic volatility, especially in small open economies. In this Mundell II world it will generally be beneficial for small open economies which allow the free movement to capital to fix their exchange rates as a way to avoid the disruptive macroeconomic effects of floating exchange rates. Since, in addition, pegged exchange rates are fragile and subject to crises, these countries will find it advantageous to join a monetary union so as to permanently fix their exchange rates.

In the following sections we take up the issue raised by Mundell II and analyse the extent to which the CEE accession countries have created a better environment for trade, capital flows and growth by stabilizing their exchange rates. This will allow us to shed light on the question of whether Mundell I or Mundell II is the appropriate framework for the new member states who are close to enter EMU?

\section{Sample Selection, Volatility Measures, Sub-Periods}

We use a panel of ten CEE countries to analyse how inflation and economic growth in the CEE countries have been affected by the exchange rate regime. Given the short observation period, which is available for the transition economies, country-specific regressions would not provide enough degrees of freedom. Even for a panel of 10 countries a nine-year sample period with a maximum of 90 observations could be criticised as being too short. Nevertheless, it can give us a 
valuable insight in the cost and benefits of EMU membership of the CEE countries by exploring both the time dimension and the country dimension of the panel.

\section{Sample}

Our sample consists of the CEE (potential) EU accession countries, i.e. the Czech Republic, Estonia, Hungary, Latvia, Lithuania, Poland, Slovak Republic, Slovenia and the "latecomers" Bulgaria and Romania. Since the macroeconomic data for the cross-country panel are incomplete prior to 1993, the observation period starts in 1994 and continues up to the present (2002).

\section{Volatility Measures}

When measuring the impact of the exchange rate regime on inflation and growth, one of the most important decisions to be made is the choice of the underlying definition of exchange rate stability. In practice, exchange rate arrangements can seldom be subdivided into fully pegged or fully flexible regimes, but they cover a broad variety of "intermediate" regimes. In addition - as stressed by a growing literature such as Reinhart and Rogoff (2002: 32), Calvo and Reinhart (2002), Levy-Yeyati and Sturzenegger (2002), McKinnon and Schnabl (2003) and Schnabl (2003) - the official announcements of (de jure) exchange rate arrangements might differ from de facto exchange rate policies.

Official IMF classifications of exchange rate arrangements as published by the IMF Annual Reports on Exchange Rate Arrangements and Exchange Restrictions have the advantage of providing a measure for the commitment by the monetary authorities in favour of specified exchange rate targets. The IMF classifies de jure exchange rate arrangements into eight groups with a rising degree of exchange rate flexibility. As shown in Table 1 the official IMF classifications range from exchange rate arrangements without separate legal tender (dollarization or euroization) up to independent floating. These eight classifications are generally sub-divided into fixed exchange rate arrangements ( 1 and 2), intermediate exchange rate arrangements (3 to 6) and flexible exchange rate arrangements (7 and 8) (Fischer 2001:3-4).

While de jure exchange rate classifications emphasize the "signalling effect for expectations", they depend on the country's ex ante self-assessment of the exchange rate regime. ${ }^{3}$ As a result, they might fail to control for a possible discrepancy between de jure and de facto regimes. Such a discrepancy often arises when "fear of floating" exists, leading countries to pursue exchange rate stabilization even when they declare their exchange rate regime to be flexible. In this case exchange rate flexibility will be less than suggested by official classifications. Although de

3 De jure exchange rate classifications might be closer to an ex ante declaration of the exchange rate regime and thus be less vulnerable to the possible endogeneity bias as discussed below. 
facto measures for exchange rate volatility suffer from a variety of shortcomings such as their backward looking nature, they have been used should provide useful information with respect to the impact of exchange rate stability on macroeconomic stability.

The methodologies to identify de facto exchange rate regimes use a combination of several indicators, i.e., observed exchange rate volatility, percentage changes in foreign reserves and absolute changes in nominal interest rates (Calvo and Reinhart (2002) or Levy-Yeyati and Sturzenegger (2002)). We focus on observed exchange rate volatility as an indicator for exchange rate stabilization. ${ }^{4}$

To measure the observed exchange rate volatility the adequate reference currency has to be chosen. Up to 1997/98 the German Mark (DM) and the US dollar competed as anchor currencies in Central and Eastern Europe. Some countries pegged their currencies to the dollar, others to the DM or to currencies baskets with a broad variety of (European) currencies. With the introduction of the euro in 1999 and the approaching EU accession of the CEE countries the euro has become the dominant anchor currency in Central and Eastern Europe (Schnabl 2003).

To satisfy both the role of the euro (DM) and the dollar as anchor currencies in Central and Eastern Europe we proceed in two steps. First, we calculate a measure for exchange rate volatility against the euro (DM) and the dollar respectively. The z-scores as proposed by Ghosh, Gulde and Wolf (2003) incorporate both exchange rate fluctuations around a constant level and exchange rate fluctuations around a gradual depreciation path. The parameter $\mu$ corresponds to the arithmetic average of month-to-month percent exchange rate changes of the year $t$ while $\sigma$ corresponds to the standard deviation of the month-to-month percent exchange rate changes of the year $t$.

$$
z_{t}=\sqrt{\mu_{t}^{2}+\sigma_{t}^{2}}
$$

The z-scores are calculated using yearly observations between 1994 and 2002 and are reported for the euro (DM) in Table 2 and the dollar in Table 3. Exchange rate volatility against the DM and the euro (EUVOL) is lowest for the currency board of Estonia and highest for the (now) free floater Poland (Table 2). Table 3 shows the declining role of dollar pegging after 1998, which has persisted only in Romania and partially in the Latvian SDR currency basket.

To compute a measure of both euro (DM) and dollar pegging in Central and Eastern Europe we calculated a measure of exchange rate stabilization by averaging the z-scores of dollar and euro pegging. ${ }^{5}$ The results are reported in Table 4 and provide us with a rough measure of nominal

McKinnon and Schnabl (2003) use a similar methodology.

Assuming that the covariance between dollar and euro (DM) is zero. 
effective exchange rate stability in Central and Eastern Europe (NOMEFF). We observe that the Latvian currency basket now achieves a higher degree of exchange rate stabilization than under the two single currency indicators. The rigid pegs of all Baltic countries maintain the highest z-scores for exchange rate stabilization.

\section{Sub-Periods}

The sample period from 1994 to 2002 covers two different social and political environments for exchange rate stabilization in Central and Eastern Europe. Up to the year 1997 the CEE exchange rate strategies were quite heterogeneous and did not follow any consistent formal or informal common guideline. While one group of countries - notably the Baltic countries-pursued rigid pegs, a second group (Bulgaria, Hungary, Poland, Romania and Slovenia) experienced persistent depreciations. The Czech and the Slovak republics exhibited considerable exchange rate fluctuations, without a clear trend however.

During 1997 and 1998 the social and political circumstances for exchange rate policies in Central and Eastern Europe changed in two respects. ${ }^{6}$ First, the 1997/98 the financial crises in Asia, South America and Central and Eastern Europe made clear that the so-called intermediate exchange rate regimes (Fischer 2001) are very fragile. Following IMF recommendations, many emerging countries adopted inflation targeting frameworks. Inflation targeting was officially introduced in the Czech Republic (1998), Poland (1999), Hungary (2001) and Slovenia (2002) which also coincided with the official shift towards flexible exchange rate arrangements. ${ }^{7}$

Second, in March 1998 the European Union started the official negotiations on EU accession with the Luxemburg group (Estonia, Czech Republic, Hungary, Poland, and Slovenia) and in October 1999 with the Helsinki group (Bulgaria, Latvia, Lithuania, Romania, and Slovak Republic). The adoption of the Acquis Communautaire by the accession countries incorporated the coordination of macroeconomic policies (art. 103, 1 EC Treaty), prohibition of central bank loans to the government (art. 104) and the control of government deficits (art. 104c). The approaching EU accession provided an informal framework for macroeconomic stabilization that is unique in the group of emerging markets. Although EU accession did not impose any direct restrictions on the exchange rate strategies, the coordination of macroeconomic policies required low inflation. The gradual depreciations in Bulgaria, Hungary, Poland and Slovenia abated or-at least—slowed down.

\footnotetext{
Coricelli and Jazbec (2003) make a similar distinction regarding sub-periods.

7 Because in small open economies the pass-through of exchange rate fluctuations to prices is high, in some countries exchange rate stabilization persisted (but without any specified target).
} 
Furthermore, anticipating membership in the European Union, exchange rate stabilization against the euro gained a more prominent weight for the CEE countries. Bulgaria adopted a DM (euro) based currency board in mid 1997, Hungary changed the weight of the euro in its currency basket to $100 \%$ in January 2002. The Lithuanian currency board switched the reference currency from the dollar to the euro in early 2002. Other CEE countries such as the Czech and the Slovak Republics announced the euro to be the official intervention currency.

\section{Exchange Rate Regime and Inflation}

The predominant view on the relationship between the exchange regime and inflation is that pegged exchange rates contribute to lower and more stable inflation. For (developing and emerging) countries with (comparatively) weak institutional frameworks pegged exchange rates provide an important tool to control inflation via both a commitment towards exchange rate stability and a disciplining effect on monetary growth (Crocket and Goldstein 1976). For small and open economies pegging the nominal exchange rate helps minimizing fluctuations of the domestic price level (McKinnon 1963).

In contrast, in countries with strong institutional frameworks (based on central bank independence) low inflation can be achieved without any specific commitment to an explicit exchange rate target (Calvo and Mishkin 2003). Recently, inflation targeting frameworks have become a widely used tool to achieve price stability in both industrial countries and emerging markets. In large (closed) economies inflation targets-which imply freely floating exchange rates - will not affect the volatility of inflation as the fraction of traded goods on the aggregate price level is comparatively small. In contrast, in smaller (more open) economies exchange rate fluctuations might impair price stability and therefore (informal) exchange stabilization might persist.

Table 5 and Table 6 show the macroeconomic performance of the CEE countries for the two sub-periods as specified in section 3. The countries are ranked according to their z-score for monthly exchange rate stability against both euro (DM) and dollar as listed in Table 4. Averages are calculated for a group with (relatively) fixed exchange rates and for a group with (relatively) flexible exchange rates.

At first glance, for the first sub-period from 1994 up to 1997 (Table 5) inflation in the pegged exchange rates group is considerably lower than in the more flexible group for both consumer and wholesale prices. But if the two high inflation countries Romania and Bulgaria are removed from the sample, this distinction disappears. Similarly, for the second sub-period, there is 
no clear indication that stable exchange rates contribute to lower inflation if the outlier Romania is removed from the sample (Table 6).

Given the complex interdependence among all macroeconomic aggregates such as prices, money, interest rates and real growth, this finding is not surprising. Fixed exchange rates might contribute to price stability, but other determinants of inflation-such as the dismantling of price controls in the transition economies - might compensate this effect.

\section{Model Specification}

To identify the effect of exchange rate policies and inflation targeting on the level of inflation we specify a cross-country panel model for the period 1994-2002. The basic framework for the analysis is a monetary model of inflation, in which inflation is determined by the growth rates of money (MON) and output (GDP). We include in this model the indicators for exchange rate stability (PEG, IMD, EUVOL, NOMEFF) and introduce dummies for inflation targeting (TARGET).

Starting from this baseline model, we add a considerable number of control variables which can influence the impact of the exchange rate stability on inflation. These control variables can be sub-dived into domestic and external variables. The domestic control variables are central bank independence (INDEP), short-term capital inflows as percent of GDP (CAPGAP) and current budget deficits as percent of GDP (DEF). The external control variables are a dummy for the 1998 financial crisis (CRISIS), EMU consumer price inflation ${ }^{8}$ (CPIEMU) and EU real growth (GDPEU). If control variables remained insignificant for all estimations and robustness checks they were removed from the estimating equation to save degrees of freedom. ${ }^{9}$ This yields the following specification:

$$
y_{i t}=\alpha_{i}+x_{i t}^{\prime} \beta_{i}+\varepsilon_{i t}
$$

where $y_{i t}$ is the vector of cross-country inflation rates over the period $1994-2002$. The regressors are denoted by $\mathrm{x}_{\mathrm{it}}$ which include the indicators of exchange rate stability, domestic control variables and external control variables and $\varepsilon_{i t}$ is the error term.

A major issue concerning the specification of equation (1) is the existence of a possible endogeneity bias. As it stands, equation (1) assumes that the causality runs from the exchange rate regime to the rate of inflation. There is, however, also a potential reverse causality, i.e. countries

Alternatively inflation in the US.

Central bank independence, short-term capital inflows, budget deficits and EMU inflation. 
with low inflation are more likely to adopt pegged exchange rates. Conversely, in countries with high inflation the probability of adopting fixed exchange rates is low.

We address the endogeneity issue by estimating a GMM model as proposed by Arellano and Bond (1991). This GMM model uses the full set of valid lags of all endogenous and exogenous variables as instruments. The exchange rate stability indicators, the dummy for inflation targeting, money supply, real growth, and absolute interest rates changes are assumed to be subject to an endogeneity bias. Real EU growth and the dummy for 1998 crisis ${ }^{10}$ are assumed to be exogenous. In addition, we introduce openness ${ }^{11}$, export concentration to EU15, as well as volatility of foreign reserves as instrumental variables, which are assumed to be correlated with exchange rate volatility but not with inflation.

\section{Estimation Results}

Following Gosh, Gulde and Wolf (2003: 75-106) the estimation process is first based on de jure exchange rate classifications. It includes dummies for pegged (PEG) and intermediate (IMD) exchange rate regimes with floating regimes as the excluded category. In this specification negative coefficients of the dummies indicate lower average inflation in comparison to flexible regimes. Positive coefficients indicate higher inflation. In a second and third step the dummies for de jure exchange rate stability are substituted by the z-scores for de facto exchange rate exchange rate stability. "De facto I" indicates exchange rate stability against the euro (DM) (EUVOL). "De facto II" indicates exchange rate stability against both euro (DM) and dollar, which can be interpreted as a simple measure of nominal effective exchange rate stability (NOMEFF). Positive coefficients indicate that pegged exchange rates (lower volatility) are associated with less inflation.

The results are reported in Table 7. For the whole observation period (1994-2002) we find that the de jure measures of exchange rate volatility are not significant. The dummy for inflation targeting is negative suggesting that inflation targeting lowers inflation. But the level of significance is low. ${ }^{12}$ The other coefficients have the expected sign although only real growth-which contributes to less inflation — and money—which contributes to more inflation — are significant at the common levels.

The results of the estimations based on de facto exchange rate variability against the euro (DM) and against an average of the euro and the dollar are presented in the second and third columns of

10 To this end we interpret the crisis as contagion from other crisis regions in East Asia and Latin America.

11 Openness also includes country size, which can be assumed to correlated with exchange rate stability, but not inflation.

12 In the baseline GLS estimation the dummy for inflation targeting was negative and significant at the $5 \%$ level. 
Table 7 (de facto I and de facto II). We find that these two measures of de facto exchange rate stability have a strong and very significant impact on inflation. Exchange stability against the euro (DM) and the dollar contributes to a lower level of inflation. The other coefficients keep the expected signs. Thus, the first step of our estimation suggests that in Central and Eastern Europe exchange rate pegs contributed significantly to lower inflation during 1994-2002.

For reasons discussed in the previous section we check for structural breaks in the estimated equation. The change in the social and political environment that occurred around 1998 may cause shifts in the coefficients of the indicators of exchange rate stability. In particular, since 1998 with inflation converging towards the EMU level, the correlation between exchange rate stability and inflation may be less evident.

To control for different impacts of the exchange rate regime on the level of inflation in different time periods we introduce dummies for the pre-EU accession period (PERIOD1) from 1994 to 1997 and the EU accession period from 1998 to 2002 (PERIOD2). In the new model the variables of exchange rate stability are multiplied by these two period dummies. For the inflation targeting this distinction is not made, because it emerged only during the second sub-period.

The results are reported in the lower panel of Table 7 (two periods model). We observe that for the de jure dummies the coefficients have the expected sign, but remain insignificant for both periods. For the de facto measures of exchange rate volatility we observe a structural break: While in the pre-EU accession period the coefficients of exchange rate stability have the right sign and are highly significant, in the second period these coefficients cease to be statistically significant.

We also tested the robustness of our results by eliminating the outliers. As found by Ghosh, Gulde and Wolf (2003), the impact of the exchange rate regime on inflation is very significant for high inflation countries, but for low inflation countries the evidence is weak. In our CEE sample, during the first sub-period Bulgaria experienced very high (hyper) inflation which coincided with the fast depreciation of the Bulgarian lev. While in the second sub-period most CEE countries including Bulgaria achieved macroeconomic stabilization, in Romania considerable inflation and strong depreciations persisted.

To control for possible bias caused by the two outliers we eliminated Bulgaria and Romania from our panel and re-estimated the model. We present the results in Table 8. One of the more striking results is that for the whole period we fail to find a significant effect of exchange rate stability on inflation for both the de jure and the de facto measures. ${ }^{13}$

In the two periods model there is a significant impact of exchange rate stability on inflation for the de facto I measure (exchange rate stability against the euro) during the first sub-period.

13 In addition the estimation process for the de jure regimes gets unstable dropping the coefficient for pegged regimes. 
During the second period the coefficient becomes negative for both measures of de facto exchange rate stability suggesting that exchange rate stability is associated with higher inflation. This is in line with De Grauwe and Schnabl (2003). The intuition is that in countries with fixed exchange rate regimes such as Estonia or Lithuania, the Balassa-Samuelson effect contributes to higher inflation. In countries with more flexible rates such as Poland or the Czech Republic, the Balassa-Samuelson effect can be adjusted by nominal appreciation leading to a lower level of inflation. As a result, inflation targeting frameworks are associated with lower inflation (negative coefficient). ${ }^{14}$

\section{Exchange Rate Regime and Output Growth}

There is an important literature on the effect of the exchange rate regime on economic growth. On the whole this literature is inconclusive. The main reason is that there are theoretical channels highlighting a positive effect of exchange rate stability on growth and others that stress the negative repercussions of exchange rate pegs on output expansion.

Proponents of fixed exchange rates have argued that stable exchange rates foster economic growth by promoting macroeconomic stability, in particular in small open economies. McKinnon and Schnabl (2003) argue for East Asia that — up to the Asian crisis — exchange rate stability against the US dollar contributed to low and stable inflation as well as to sound government finance. The resulting stable expectations in turn promoted investment and long-term growth (the East Asian miracle).

One can identify two reasons why exchange rate stability promotes higher economic growth. First, the elimination of foreign exchange risk stimulates international trade and thereby the international division of labour. While the evidence for the positive impact of exchange rate stability on trade has remained mixed (European Commission 1990, IMF 1984), recently, Frankel and Rose (2002) have found a strong positive impact of irrevocably fixed exchange rates on trade and income in the context of a monetary union. Second, credible fixed exchange rate regimes create an environment of macroeconomic stability thereby reducing the risk premium embedded in the real interest rate. The resulting lower long-term interest rates stimulate investment, consumption and growth (Dornbusch 2001).

In contrast to this view, Meade (1951) and Friedman (1953) have argued that under flexible exchange rates countries can adjust to real shocks more easily. Under fixed exchange rate regimes real exchange rate adjustments must be carried out through relative price changes, which in a world of price rigidities is slow and costly. This may create an excessive burden on the economy leading to low economic growth.

14 Note that the negative coefficients are insignificant at the common levels, however. 
Furthermore, the recent experience of currency crises has highlighted the costs of maintaining exchange rate pegs under free capital mobility (Fischer 2001). Less than fully credible pegs become victims of speculative attacks and painful recessions when the pegs collapse. Even if the peg can be defended in times of crisis the costs in terms of rising interest rates are high. As a result, flexible exchange rates constitute a more appropriate regime to avoid crises and to achieve stable long-term growth.

Since economic theory does not allow us to make precise predictions, the question of whether exchange rate stability leads to more or less economic growth is essentially an empirical matter. Not surprisingly, since the theory is inconclusive, empirical studies have also come to different conclusions. Comparing growth in industrial countries during and after the Bretton-Woods System, Mundell (1995) finds faster growth in times of exchange rate stability. Bailliu, Lafrance and Perrault (2003) argue that intermediate and flexible exchange rates are detrimental for growth. The GLS estimation by Ghosh, Gulde and Wolf (2003) yields a weak relationship between the exchange rate regime and growth.

In contrast, the panel estimation by Edwards and Levy-Yeyati (2003) finds evidence that countries with more flexible exchange rates grow faster. Eichengreen and Leblang (2003) reveal a strong negative relationship between the exchange rate regime and growth for 12 countries over 120 years. They conclude that the results of such estimations strongly depend on the time period and the sample.

We are interested in the impact of the exchange regime on the growth rates of the CEE countries during their transition towards the European Union. Table 5 and Table 6 show the average yearly GDP growth rates in the CEE countries. As in section 4, the sample is subdivided in two groups, one with relatively fixed and one with relatively flexible exchange rates. We use the z-score of average exchange rate volatility against both euro (DM) and dollar. We find some evidence of a higher average growth in the group with relatively fixed exchange rate arrangements. This result holds for both sub-periods and even if the "outliers" Romania and Bulgaria are excluded.

\section{Model Specification}

To provide better evidence of the impact of the exchange rate regime on growth in Central and Eastern Europe we use a panel data model that explains economic growth by standard variables from the growth literature to which we add the measures of exchange rate stability. ${ }^{15}$ This yields the following regression equation:

15 See Ghosh, Gulde and Wolf (2003) and Edwards and Levy-Yeyati (2003) for a similar approach 


$$
w_{i t}=\gamma_{i}+v_{i t}^{\prime} \delta_{i}+\varepsilon_{i t}
$$

where $\mathrm{w}_{\mathrm{it}}$ is the vector of yearly real growth rates during 1994-2002 in the CEE-countries. The explanatory variables $\mathrm{v}_{\text {it }}$ consist of the indicators of exchange rate stability and a set of control variables. These control variables are the ratio of investment to GDP (INVGDP), the growth rate of dollar exports (EXPGR), the budget deficit as percent of GDP (DEF), short-term capital inflows as percent of GDP (CAPGDP), and real growth of the EU15. Furthermore, we include dummies for the 1998 crisis and inflation targeting. ${ }^{16}$

\section{Estimation Results}

The results of estimating the growth equation (2) are reported in Table $9 .{ }^{17}$ We find that the de jure exchange rate stability variables have a weak and mostly insignificant effect on economic growth. This contrasts with the results obtained with the de facto exchange rate stability variable. The coefficients of the de facto exchange rate measures have both negative signs and are highly significant at the $1 \%$ level. This result holds for the whole period and for the two sub-periods. Thus, we cannot reject the hypothesis that exchange rate stability promotes economic growth in the CEE economies. Our findings for the CEE countries appear to be stronger than in the all-country sample of Ghosh, Gulde and Wolf (2003) and are in stark contrast with the findings of Edwards and LevyYeyati (2003).

In contrast with the results of the previous section, we do not find evidence that inflation targeting contributed to more growth in the CEE countries. The other control variables have the expected signs and are statistically significant. We also performed an estimation of the panel data model excluding the outliers, Romania and Bulgaria (Table 10). On the whole our main conclusion that exchange rate stability (measured by de facto stability) has promoted economic growth in the CEE-countries is maintained. This conclusion seems to be rather robust.

\section{Conclusion}

What do our findings mean for the new member states in the European Union? With the accession to the European Union, the CEE countries moved from a period of macroeconomic instability to a more stable macroeconomic environment.

16 Control variables which represent workers education are less important for our sample, because they can be assumed to be by and large the same for the observation period and all countries.

17 We perform a standard GLS estimation as the concern for a possible endogeneity bias is small. 
Our estimations of the impact of the exchange rate regime on economic growth suggest that exchange rate fixity does not reduce economic growth in the CEE countries. On the contrary, by fixing exchange rates to the euro, the CEE countries can reap the benefits of more trade (Frankel and Rose 2002) and lower interest rates (Dornbusch 2001). The view that the entry in the Eurozone will put constraints on the growth potential of the CEE countries is not warranted. The evidence also shows that for these small open economies stabilizing exchange rates has been a source of macroeconomic stability. The Mundell II framework seems to be the right one to think about the desirability of joining the Eurozone.

This does not mean that the Mundell I framework has become irrelevant. There are still risks involved for the CEE countries when they join EMU. These risks arise because of the possibility of future large asymmetric shocks. Our results, however, suggest that against these risks there is the high growth potential that the CEE countries are likely to enjoy in EMU. All this leads to some optimism about the benefits of monetary union for the new member states. 


\section{References}

Alvarez-Plata, Patricia / Brückner, Herbert / Siliverstovs, Boriss (2003): Potential Migration from Central and Eastern Europe into the EU-15 - An Update, Berlin.

Arellano, Manuel / Bond, Stephen 1991: Some Tests of Specification for Panel Data: Monte Carlo Evidence and an Application to Employment Equations. Review of Economic Studies 58, 277 297.

Backé, Peter / Thimann, Christian 2004: The Acceding Countries' Strategies towards ERMII and the Adoption of the Euro: an Analytical Review. Mimeo.

Bailliu Jeannine / Lafrance, Robert / Perrault, Jean-Francois 2003: Does Exchange Rate Policy Matter for Growth? International Finance 6, 3.

Bayoumi, Tamin / Eichengreen, Barry 1993: Shocking Aspects of European Monetary Integration. In Torres, Francisco / Giavazzi, Francesco (eds.): Adjustment and Growth in the European Monetary Union, London, 193-229.

Blanchard, Olivier / Quah, Danny 1989: The Dynamic Effects of Aggregate Demand and Supply Disturbances. American Economic Review 79, 655-673.

Buiter, Willem / Grafe, Clemens 2002: Anchor, Float or Abandon Ship: Exchange Rate Regimes for Accession Countries. CEPR Discussion Paper No. 3184.

Calvo, Guillermo / Mishkin, Frederic 2003: The Mirage of Exchange Rate Regimes for Emerging Market Countries. Journal of Economic Perspectives 17, 99-118.

Calvo, Guillermo / Reinhart, Carmen 2002: Fear of Floating. Quarterly Journal of Economics 117, 379-408.

Coricelli, Fabrizio / Jazbec, Boštjan 2003: Real Exchange Rate Dynamics in Transition Economies. Forthcoming in Structural Change and Economic Dynamics.

Crockett, Andrew / Goldstein, Morris 1976: Inflation under Fixed and Flexible Exchange Rates. IMF Staff Papers 23, 509-544.

Cukierman, Alex / Miller, Geoffrey / Neyapti, Bilin 2002: Central Bank Reform, Liberalization and Inflation in Transition Economies - an International Perspective. Journal of Monetary Economics 49, 237-264.

De Grauwe, Paul 2003: Economics of Monetary Union, Oxford.

De Grauwe, Paul / Schnabl, Gunther 2003: Nominal versus Real Convergence with Respect to EMU Accession. How to Cope with the Balassa-Samuelson Dilemma. Mimeo.

Deutsche Bundesbank 2003: Monthly Report July 2003.

Dornbusch, Rüdiger 2001: Fewer Monies Better Monies, Discussion on Exchange Rates and the Choice of Monetary-Policy Regimes, American Economic Review 91, 238-242. 
Edwards, Sebastian / Levy-Yeyati, Eduardo 2003: Flexible Exchange Rates as Shock Absorbers. Mimeo.

Eichengreen, Barry / Lebland, David 2003: Exchange Rates and Cohesion. Journal of Common Market Studies 41, 797-822.

European Commission 1990: One Market, One Money: An Evaluation of the Potential Benefits and Costs of Forming an Economic and Monetary Union. European Economy 44.

Fidrmuc, Jarko / Korhonen, Iikka 2002: Similarity of Supply and Demand Shocks between the Euro Area and the CEECs. Mimeo.

Fischer, Stanley 2001: Exchange Rate Regimes: Is the Bipolar View Correct? Journal of Economic Perspectives 15, 3-24.

Frankel, Jeffrey / Rose, Andrew 1998: The Endogeneity of the Optimum Currency Area Criteria. Economic Journal 108, 1009-1025.

Frankel, Jeffrey / Rose, Andrew 2002: An Estimate of the Effect of Common Currencies on Trade and Income. Quarterly Journal of Economics 117, 437-466.

Friedman, Milton 1953: The Case for Flexible Exchange Rates. In Friedman, Milton: Essays of Positive Economics, Chicago, London.

Ghosh, Atish / Gulde, Anne-Marie / Wolf, Holger 2003: Exchange Rate Regimes. Choices and Consequences, Cambridge (Massachusetss).

International Monetary Fund 1984: Exchange Rate Variability and World Trade. Occasional Paper 28.

International Monetary Fund (various issues): Annual Report on Exchange Rate Arrangements and Exchange Restrictions, Washington D.C.

Levy-Yeyati, Eduardo / Sturzenegger, Federico 2002: Classifying Exchange Rate Regimes: Deeds vs. Words. Mimeo.

McKinnon, Ronald 1963: Optimum Currency Areas. American Economic Review 53, 207-222.

McKinnon, Ronald 2003: Optimum Currency Areas and Key Currencies: Mundell I versus Mundell II. Mimeo.

McKinnon, Ronald / Schnabl, Gunther 2003: The East Asian Dollar Standard, Fear of Floating, and Original Sin. Hong Kong Institute for Monetary Research Working Paper No. 11/2003.

Meade, James 1951: The Theory of International Economic Policy.

Micco, Alejandro / Stein, Ernesto / Ordoñez, Guillermo 2003: The Currency Union Effect on Trade: Early Evidence from EMU. Economic Policy 37, 315-356.

Mundell, Robert 1961: A Theory of Optimal Currency Areas. American Economic Review 51, 657665. 
Mundell, Robert 1973a: Uncommon Arguments for Common Currencies. In Johnson, Harry / Swoboda, Alexander (eds.): The Economics of Common Currencies, London, 114-132.

Mundell, Robert 1973b: A Plan for a European Currency. In Johnson, Harry / Swoboda, Alexander (eds.): The Economics of Common Currencies, London, 143-172.

Mundell, Robert 1995: Exchange Rate Systems and Economic Growth. Rivista de Politica Economica 85, 1-36.

Reinhart, Carmen / Rogoff, Kenneth 2002: The Modern History of Exchange Rate Arrangements: A Reinterpretation. NBER Working Paper No. 8963.

Riboud, Michelle / Sánchez-Páramo, Carolina / Silva-Jáuregui, Carlos (2002): Does Eurosclerosis Matter? Institutional Reform and Labor Market Performance in Central and Eastern European Countries in the 1990s. World Bank Social Protection Discussion Paper 202.

Schnabl, Gunther 2003: De jure versus de facto Exchange Rate Stabilization in Central and Eastern Europe. Tübinger Diskussionsbeitrag 269, October 2003. 
Figure 1: Cost and Benefits of Monetary Union: Asymmetry, Flexibility and Openness

\section{asymmetry}

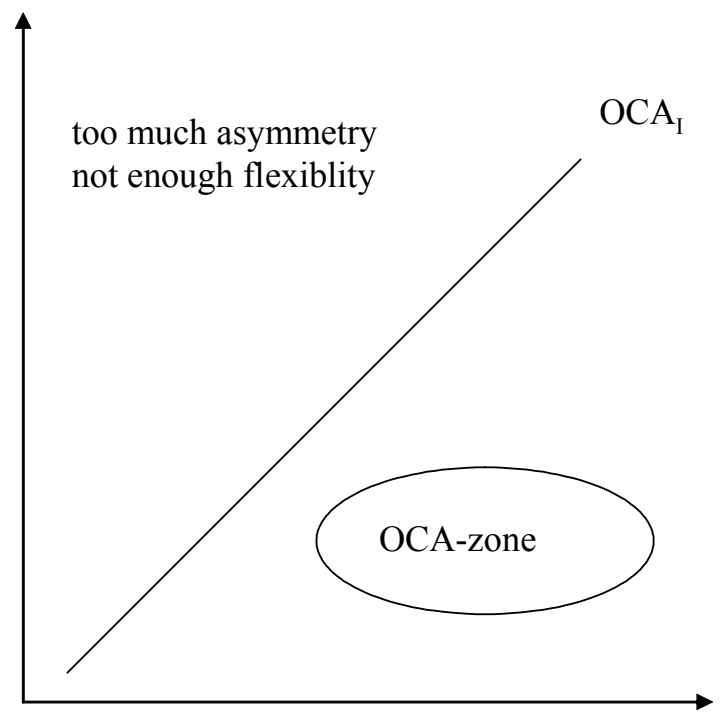

flexibility asymmetry

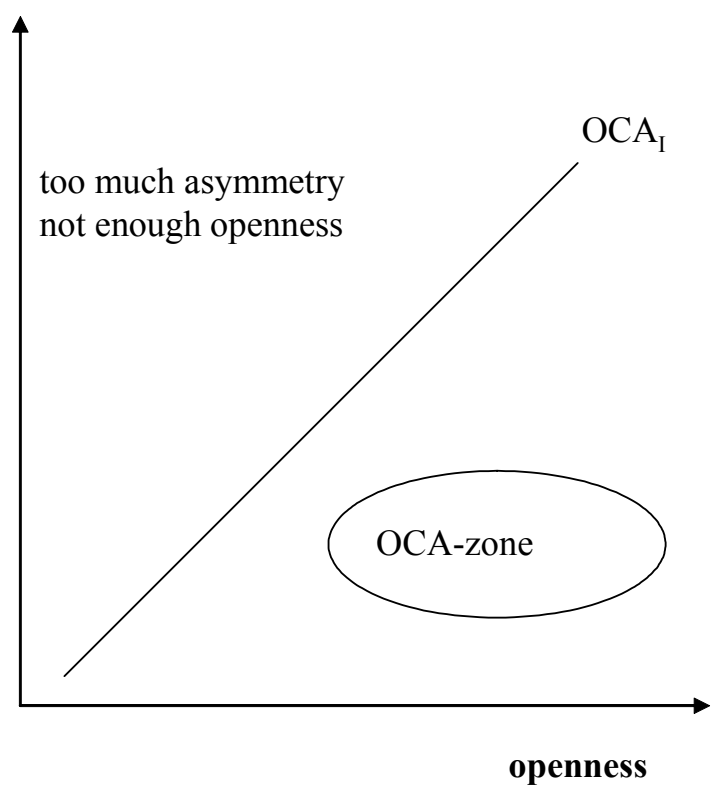


Figure 2: Exports to EU15 as Percent of GDP (2002)

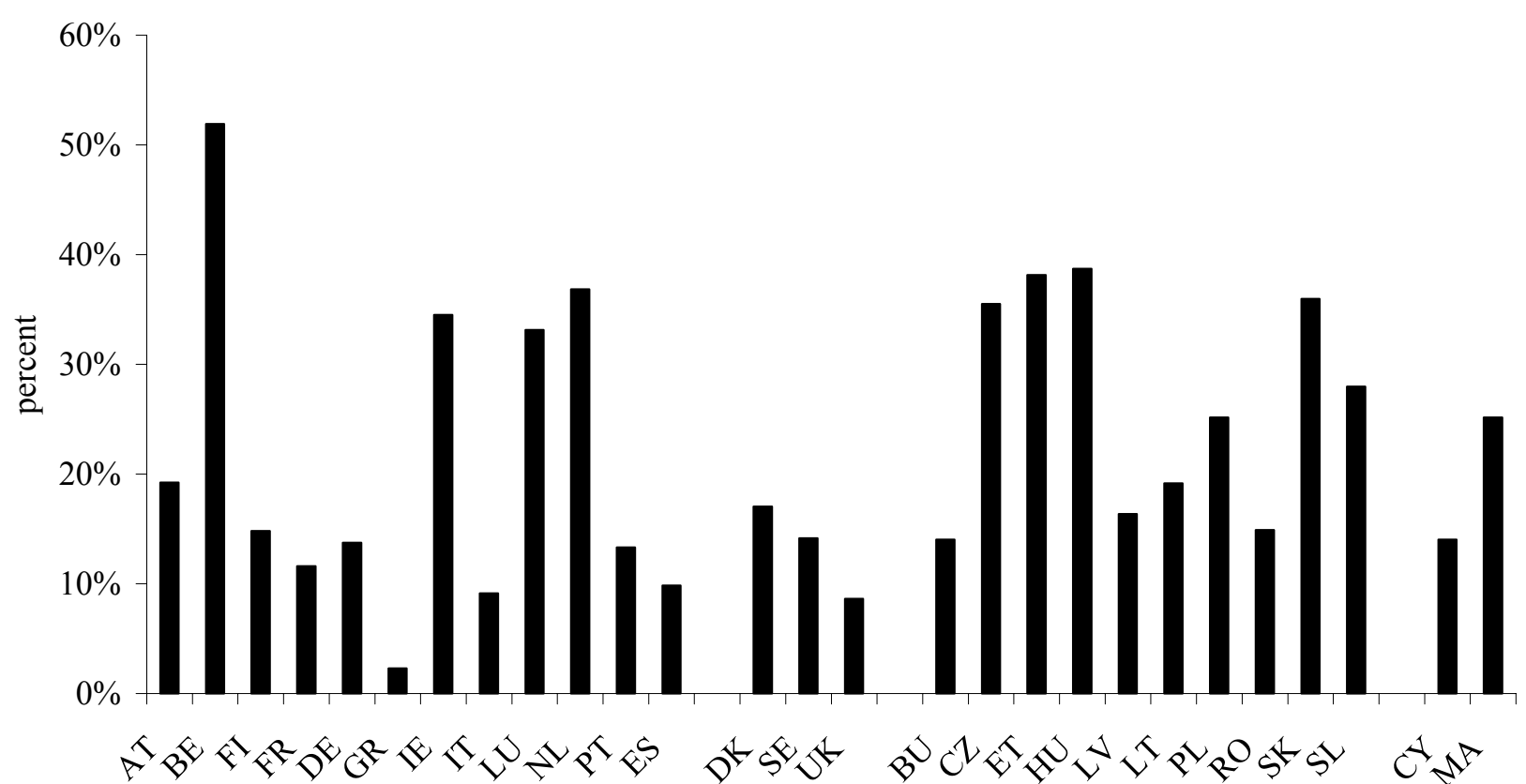

Source: IMF: Direction of Trade Statistics. 
Table 1: De jure Exchange Rate Arrangements in Central and Eastern Europe

\begin{tabular}{lcccccccccccccc}
\hline & $\mathbf{9 0}$ & $\mathbf{9 1}$ & $\mathbf{9 2}$ & $\mathbf{9 3}$ & $\mathbf{9 4}$ & $\mathbf{9 5}$ & $\mathbf{9 6}$ & $\mathbf{9 7}$ & $\mathbf{9 8}$ & $\mathbf{9 9}$ & $\mathbf{0 0}$ & $\mathbf{0 1}$ & $\mathbf{0 2}$ & $\mathbf{0 3}$ \\
\hline Bulgaria & 3 & 8 & 8 & 8 & 8 & 8 & 8 & 2 & 2 & 2 & 2 & 2 & 2 & 2 \\
Czech Rep. & 3 & 3 & 3 & 3 & 3 & 3 & 6 & 7 & 7 & 7 & 7 & 8 & 8 & 8 \\
Estonia & n.a. & n.a. & 2 & 2 & 2 & 2 & 2 & 2 & 2 & 2 & 2 & 2 & 2 & 2 \\
Hungary & 3 & 3 & 3 & 3 & 3 & 6 & 6 & 6 & 6 & 6 & 6 & 4 & 4 & 4 \\
Latvia & n.a. & n.a. & 8 & 8 & 3 & 3 & 3 & 3 & 3 & 3 & 3 & 3 & 3 & 3 \\
Lithuania & n.a. & n.a. & 8 & 8 & 2 & 2 & 2 & 2 & 2 & 2 & 2 & 2 & 2 & 2 \\
Poland & 3 & 5 & 5 & 5 & 5 & 6 & 6 & 6 & 6 & 6 & 8 & 8 & 8 & 8 \\
Romania & 3 & 7 & 7 & 7 & 7 & 7 & 7 & 7 & 7 & 7 & 7 & 6 & 6 & 6 \\
Slovak Rep. & 3 & 3 & 3 & 3 & 3 & 3 & 6 & 6 & 7 & 7 & 7 & 7 & 7 & 7 \\
Slovenia & n.a. & n.a. & 7 & 7 & 7 & 7 & 7 & 7 & 7 & 7 & 7 & 7 & 7 & 7 \\
\hline
\end{tabular}

Source: IMF (various issues).

1: exchange rate arrangements with no separate legal tender

2: currency board arrangements

3: other conventional fixed peg arrangements (within a band of most $\pm 1 \%$ )

4: pegged exchange rate arrangements within horizontal bands (at least $\pm 1 \%$ )

5: crawling pegs (with small, pre-announced adjustment)

6: exchange rates with crawling bands

7: managed floating with no pre-announced path for the exchange rate

8: independent floating (market-determined exchange rate and independent monetary policy)

Table 2: Z-Score for Monthly Exchange Rate Changes against the DM (€)

\begin{tabular}{lrlllllllll}
\hline \multicolumn{1}{c}{ BUL } & CZE & EST & HUN & LAT & LIT & POL & ROM & SLK & SLO \\
\hline 1990 & & & & & & & & & & \\
1991 & & & & & & & & & & \\
1992 & $3.10 \%$ & & & $1.74 \%$ & & & $3.95 \%$ & $14.64 \%$ & & $7.60 \%$ \\
1993 & $13.58 \%$ & & $0.00 \%$ & $1.93 \%$ & $4.48 \%$ & $10.01 \%$ & $3.63 \%$ & $8.44 \%$ & & $2.14 \%$ \\
1994 & $16.01 \%$ & $0.75 \%$ & $0.00 \%$ & $2.56 \%$ & $1.53 \%$ & $2.11 \%$ & $2.18 \%$ & $7.18 \%$ & $0.88 \%$ & $0.77 \%$ \\
1995 & $2.81 \%$ & $0.97 \%$ & $0.00 \%$ & $3.89 \%$ & $1.47 \%$ & $2.81 \%$ & $2.22 \%$ & $4.98 \%$ & $1.32 \%$ & $1.11 \%$ \\
1996 & $26.49 \%$ & $0.81 \%$ & $0.00 \%$ & $1.07 \%$ & $1.30 \%$ & $1.54 \%$ & $1.20 \%$ & $3.69 \%$ & $0.63 \%$ & $0.84 \%$ \\
1997 & $67.67 \%$ & $2.12 \%$ & $0.00 \%$ & $1.17 \%$ & $1.86 \%$ & $2.49 \%$ & $1.71 \%$ & $12.91 \%$ & $1.18 \%$ & $0.67 \%$ \\
1998 & $0.00 \%$ & $1.86 \%$ & $0.00 \%$ & $1.88 \%$ & $1.74 \%$ & $2.27 \%$ & $4.66 \%$ & $4.25 \%$ & $2.55 \%$ & $0.50 \%$ \\
1999 & $0.00 \%$ & $1.72 \%$ & $0.00 \%$ & $0.85 \%$ & $1.73 \%$ & $2.19 \%$ & $2.40 \%$ & $4.53 \%$ & $1.50 \%$ & $0.63 \%$ \\
2000 & $0.00 \%$ & $1.00 \%$ & $0.00 \%$ & $0.44 \%$ & $2.19 \%$ & $3.04 \%$ & $2.03 \%$ & $3.41 \%$ & $1.47 \%$ & $0.65 \%$ \\
2001 & $0.00 \%$ & $1.09 \%$ & $0.00 \%$ & $1.78 \%$ & $1.63 \%$ & $2.39 \%$ & $3.29 \%$ & $3.01 \%$ & $1.46 \%$ & $0.49 \%$ \\
2002 & $0.00 \%$ & $1.94 \%$ & $0.00 \%$ & $1.27 \%$ & $1.38 \%$ & $0.69 \%$ & $2.59 \%$ & $2.45 \%$ & $1.89 \%$ & $0.54 \%$ \\
\hline $94-97 *$ & $31.39 \%$ & $1.30 \%$ & $0.00 \%$ & $2.11 \%$ & $1.58 \%$ & $2.24 \%$ & $2.39 \%$ & $6.60 \%$ & $1.31 \%$ & $0.78 \%$ \\
$98-02 *$ & $0.00 \%$ & $1.44 \%$ & $0.00 \%$ & $1.09 \%$ & $1.73 \%$ & $2.08 \%$ & $2.58 \%$ & $3.35 \%$ & $1.58 \%$ & $0.58 \%$ \\
\hline
\end{tabular}

Source: IMF: IFS. DM represents the euro starting in 1999. * arithmetic average. 
Table 3: Z-Score for Monthly Exchange Rate Changes against the Dollar

\begin{tabular}{lrlllllllll}
\hline & BUL & CZE & EST & HUN & LAT & LIT & POL & ROM & SLK & SLO \\
\hline 1990 & & & & & & & & & & \\
1991 & & & & & & & & & & \\
1992 & & & & $1.79 \%$ & & & $4.77 \%$ & $12.12 \%$ & & $9.25 \%$ \\
1993 & $14.43 \%$ & & $2.52 \%$ & $2.43 \%$ & $4.24 \%$ & $9.31 \%$ & $3.03 \%$ & $9.19 \%$ & & $3.66 \%$ \\
1994 & $16.05 \%$ & $1.23 \%$ & $1.89 \%$ & $2.24 \%$ & $1.34 \%$ & $0.56 \%$ & $1.47 \%$ & $7.11 \%$ & $1.09 \%$ & $1.96 \%$ \\
1995 & $0.00 \%$ & $1.85 \%$ & $2.78 \%$ & $2.31 \%$ & $1.97 \%$ & $0.00 \%$ & $1.44 \%$ & $4.14 \%$ & $1.69 \%$ & $2.85 \%$ \\
1996 & $27.32 \%$ & $1.39 \%$ & $1.27 \%$ & $1.58 \%$ & $1.05 \%$ & $0.00 \%$ & $1.30 \%$ & $3.90 \%$ & $1.13 \%$ & $1.96 \%$ \\
1997 & $71.97 \%$ & $2.99 \%$ & $2.56 \%$ & $2.32 \%$ & $1.34 \%$ & $0.00 \%$ & $2.37 \%$ & $14.89 \%$ & $1.64 \%$ & $2.54 \%$ \\
1998 & $2.28 \%$ & $2.81 \%$ & $2.18 \%$ & $1.41 \%$ & $1.38 \%$ & $0.00 \%$ & $3.74 \%$ & $3.19 \%$ & $1.41 \%$ & $2.26 \%$ \\
1999 & $2.17 \%$ & $3.40 \%$ & $2.21 \%$ & $2.09 \%$ & $1.10 \%$ & $0.00 \%$ & $2.95 \%$ & $5.95 \%$ & $2.94 \%$ & $2.52 \%$ \\
2000 & $3.08 \%$ & $3.30 \%$ & $3.07 \%$ & $3.20 \%$ & $1.18 \%$ & $0.00 \%$ & $3.16 \%$ & $3.13 \%$ & $4.09 \%$ & $3.40 \%$ \\
2001 & $2.37 \%$ & $2.06 \%$ & $2.32 \%$ & $2.15 \%$ & $1.22 \%$ & $0.00 \%$ & $2.36 \%$ & $1.81 \%$ & $1.44 \%$ & $2.39 \%$ \\
2002 & $2.18 \%$ & $3.17 \%$ & $2.17 \%$ & $2.32 \%$ & $1.39 \%$ & $2.09 \%$ & $1.91 \%$ & $0.95 \%$ & $1.92 \%$ & $2.08 \%$ \\
\hline $94-97 *$ & $33.85 \%$ & $2.05 \%$ & $2.19 \%$ & $1.97 \%$ & $1.42 \%$ & $0.11 \%$ & $2.06 \%$ & $6.64 \%$ & $1.39 \%$ & $2.31 \%$ \\
$98-02 *$ & $2.45 \%$ & $2.98 \%$ & $2.44 \%$ & $2.44 \%$ & $1.23 \%$ & $0.52 \%$ & $2.59 \%$ & $2.96 \%$ & $2.60 \%$ & $2.60 \%$ \\
\hline S0ur
\end{tabular}

Source: IMF: IFS. DM represents the euro starting in 1999. * arithmetic average.

Table 4: Z-Score for Monthly Exchange Rate Changes against DM (€) and \$*

\begin{tabular}{lrlllllllll}
\hline & BUL & CZE & EST & HUN & LAT & LIT & POL & ROM & SLK & SLO \\
\hline 1990 & & & & & & & & & & \\
1991 & & & & & & & & & & \\
1992 & $1.55 \%$ & & & $1.77 \%$ & & & $4.36 \%$ & $13.38 \%$ & & $4.63 \%$ \\
1993 & $14.01 \%$ & & $1.26 \%$ & $2.18 \%$ & $4.36 \%$ & $9.66 \%$ & $3.33 \%$ & $8.81 \%$ & & $1.83 \%$ \\
1994 & $16.03 \%$ & $0.99 \%$ & $0.94 \%$ & $2.40 \%$ & $1.44 \%$ & $1.34 \%$ & $1.82 \%$ & $7.14 \%$ & $0.98 \%$ & $1.37 \%$ \\
1995 & $1.40 \%$ & $1.41 \%$ & $1.39 \%$ & $3.10 \%$ & $1.72 \%$ & $1.40 \%$ & $1.83 \%$ & $4.56 \%$ & $1.50 \%$ & $1.98 \%$ \\
1996 & $26.90 \%$ & $1.10 \%$ & $0.63 \%$ & $1.33 \%$ & $1.17 \%$ & $0.77 \%$ & $1.25 \%$ & $3.79 \%$ & $0.88 \%$ & $1.40 \%$ \\
1997 & $69.82 \%$ & $2.56 \%$ & $1.28 \%$ & $1.74 \%$ & $1.60 \%$ & $1.24 \%$ & $2.04 \%$ & $13.90 \%$ & $1.41 \%$ & $1.60 \%$ \\
1998 & $1.14 \%$ & $2.34 \%$ & $1.09 \%$ & $1.64 \%$ & $1.56 \%$ & $1.14 \%$ & $4.20 \%$ & $3.72 \%$ & $1.98 \%$ & $1.38 \%$ \\
1999 & $1.08 \%$ & $2.56 \%$ & $1.11 \%$ & $1.47 \%$ & $1.42 \%$ & $1.09 \%$ & $2.67 \%$ & $5.24 \%$ & $2.22 \%$ & $1.57 \%$ \\
2000 & $1.54 \%$ & $2.15 \%$ & $1.53 \%$ & $1.82 \%$ & $1.68 \%$ & $1.52 \%$ & $2.60 \%$ & $3.27 \%$ & $2.78 \%$ & $2.02 \%$ \\
2001 & $1.18 \%$ & $1.58 \%$ & $1.16 \%$ & $1.97 \%$ & $1.43 \%$ & $1.19 \%$ & $2.83 \%$ & $2.41 \%$ & $1.45 \%$ & $1.44 \%$ \\
2002 & $1.09 \%$ & $2.55 \%$ & $1.08 \%$ & $1.80 \%$ & $1.39 \%$ & $1.39 \%$ & $2.25 \%$ & $1.70 \%$ & $1.90 \%$ & $1.31 \%$ \\
\hline $94-97 *$ & $23.06 \%$ & $1.68 \%$ & $1.07 \%$ & $2.04 \%$ & $1.50 \%$ & $1.18 \%$ & $2.23 \%$ & $6.62 \%$ & $1.35 \%$ & $1.54 \%$ \\
$98-02 *$ & $1.22 \%$ & $2.21 \%$ & $1.22 \%$ & $1.76 \%$ & $1.48 \%$ & $1.30 \%$ & $2.59 \%$ & $3.15 \%$ & $2.09 \%$ & $1.59 \%$ \\
\hline
\end{tabular}

Source: IMF: IFS. DM represents the euro starting in 1999. * arithmetic average. 
Table 5: Exchange Rate Regime and Macroeconomic Performance 1994-1997

\begin{tabular}{lccccccc}
\hline & MB & MON & INT & WPI & CPI & EXP & GDP \\
\hline EST & $22.85 \%$ & $28.07 \%$ & $5.15 \%$ & $16.25 \%$ & $27.52 \%$ & $39.23 \%$ & $4.00 \%$ \\
LIT & $28.43 \%$ & $31.92 \%$ & $31.51 \%$ & $23.65 \%$ & $36.33 \%$ & $18.38 \%$ & $13.44 \%$ \\
SLK & $25.39 \%$ & $9.61 \%$ & - & $6.90 \%$ & $8.80 \%$ & $11.77 \%$ & $5.78 \%$ \\
LAT & $18.81 \%$ & $21.37 \%$ & $19.10 \%$ & $11.63 \%$ & $21.74 \%$ & $14.52 \%$ & $2.97 \%$ \\
SLO & $30.20 \%$ & $24.12 \%$ & $16.24 \%$ & $10.85 \%$ & $13.18 \%$ & $8.68 \%$ & $4.43 \%$ \\
\hline Average 1 & $25.14 \%$ & $23.02 \%$ & $18.00 \%$ & $13.86 \%$ & $21.51 \%$ & $18.52 \%$ & $6.12 \%$ \\
\hline CZE & $22.12 \%$ & $13.58 \%$ & $13.44 \%$ & $5.63 \%$ & $9.12 \%$ & $12.72 \%$ & $2.92 \%$ \\
HUN & $9.34 \%$ & $14.42 \%$ & $25.77 \%$ & $20.73 \%$ & $22.26 \%$ & $20.98 \%$ & $2.58 \%$ \\
POL & $30.53 \%$ & $33.44 \%$ & $23.05 \%$ & $20.25 \%$ & $24.05 \%$ & $16.53 \%$ & $6.27 \%$ \\
ROM & $82.91 \%$ & $72.78 \%$ & - & $95.6 \%$ & $90.65 \%$ & $15.21 \%$ & $2.24 \%$ \\
BUL & $256.47 \%$ & $280.55 \%$ & $76.46 \%$ & $576.64 \%$ & $334.53 \%$ & $10.27 \%$ & $-1.66 \%$ \\
\hline Average 2 & $70.27 \%$ & $82.95 \%$ & $34.68 \%$ & $143.77 \%$ & $96.12 \%$ & $15.14 \%$ & $2.47 \%$ \\
Average 2* & $20.66 \%$ & $20.48 \%$ & $20.75 \%$ & $15.54 \%$ & $18.48 \%$ & $16.74 \%$ & $3.92 \%$ \\
\hline S & $2045 \%$ &
\end{tabular}

Source: IMF: IFS. * Excluding Bulgaria and Romania. Yearly data. MB = monetary base, $\mathrm{MON}=$ money, INT $=$ short-term (money market) interest rate, $\mathrm{WPI}=$ wholesale price index, $\mathrm{CPI}=$ consumer price index, EXP = dollar exports, GDP = growth rate of real GDP. Arithmetic averages.

Table 6: Exchange Rate Regime and Macroeconomic Performance 1998-2002

\begin{tabular}{lccccccc}
\hline & MB & MON & INT & WPI & CPI & EXP & GDP \\
\hline EST & $7.34 \%$ & $15.02 \%$ & $6.38 \%$ & $2.54 \%$ & $4.97 \%$ & $3.30 \%$ & $4.74 \%$ \\
BUL & $15.15 \%$ & $17.99 \%$ & $2.93 \%$ & $8.46 \%$ & $8.95 \%$ & $3.75 \%$ & $3.98 \%$ \\
LIT & $10.09 \%$ & $10.73 \%$ & $4.31 \%$ & $0.84 \%$ & $1.69 \%$ & $8.90 \%$ & $4.56 \%$ \\
LAT & $11.54 \%$ & $13.23 \%$ & $4.07 \%$ & $0.23 \%$ & $2.28 \%$ & $6.49 \%$ & $5.69 \%$ \\
SLO & $15.32 \%$ & $24.97 \%$ & $6.62 \%$ & $5.97 \%$ & $7.77 \%$ & $2.59 \%$ & $3.90 \%$ \\
\hline Average 1 & $11.89 \%$ & $313.78 \%$ & $4.86 \%$ & $3.61 \%$ & $5.13 \%$ & $5.01 \%$ & $4.57 \%$ \\
\hline HUN & $14.29 \%$ & $16.65 \%$ & $12.65 \%$ & $6.12 \%$ & $9.70 \%$ & $12.58 \%$ & $4.27 \%$ \\
SLK & $8.54 \%$ & $8.84 \%$ & - & $5.11 \%$ & $7.99 \%$ & $12.31 \%$ & $3.04 \%$ \\
CZE & $-1.26 \%$ & $15.50 \%$ & $5.68 \%$ & $2.62 \%$ & $4.63 \%$ & $11.04 \%$ & $1.54 \%$ \\
POL & $7.13 \%$ & $13.36 \%$ & $15.59 \%$ & $4.66 \%$ & $7.31 \%$ & $9.91 \%$ & $5.46 \%$ \\
ROM & $56.50 \%$ & $36.68 \%$ & $15.81 \%$ & $39.36 \%$ & $41.51 \%$ & $10.90 \%$ & $1.35 \%$ \\
\hline Average 2 & $17.04 \%$ & $18.21 \%$ & $12.43 \%$ & $11.57 \%$ & $14.23 \%$ & $11.35 \%$ & $3.13 \%$ \\
Average 2* & $7.19 \%$ & $13.66 \%$ & $9.17 \%$ & $4.62 \%$ & $7.44 \%$ & $11.98 \%$ & $2.95 \%$ \\
\hline SOurce & & &
\end{tabular}

Source: IMF: IFS. * Excluding Romania. Yearly data. MB $=$ monetary base, MON = money, INT $=$ short-term (money market) interest rate, $\mathrm{WPI}=$ wholesale price index, $\mathrm{CPI}=$ consumer price index, $\mathrm{EXP}=$ dollar exports, GDP $=$ growth rate of real GDP. Arithmetic averages. 
Table 7: Arelleano-Bond Panel Estimation for Inflation - All Countries

\begin{tabular}{|c|c|c|c|c|c|c|}
\hline \multirow{2}{*}{$\begin{array}{l}10 \text { Countries } \\
\text { One Period Model }\end{array}$} & \multicolumn{2}{|c|}{ de jure } & \multicolumn{2}{|c|}{ de facto $I$} & \multicolumn{2}{|c|}{ de facto II } \\
\hline & coeff. & z-stat & coeff. & z-stat & coeff. & z-stat \\
\hline CPI (lags) & -0.005 & -0.25 & 0.007 & 0.42 & 0.010 & 0.66 \\
\hline PEG & 0.138 & 0.75 & & & & \\
\hline IMD & -0.088 & -0.88 & & & & \\
\hline EUVOL & & & $2.281 * *$ & 2.59 & & \\
\hline NOMEFF & & & & & $4.870 * * *$ & 4.68 \\
\hline TARGET & -0.068 & -0.68 & -0.023 & -0.26 & -0.017 & -0.20 \\
\hline GDP & $-1.112 * * *$ & -2.84 & $-0.684^{*}$ & -1.73 & -0.243 & -0.66 \\
\hline MON & $1.140 * * *$ & 52.22 & $0.994 * * *$ & 15.14 & $0.815 * * *$ & 10.79 \\
\hline GDPEU & 2.000 & 0.61 & 3.950 & 1.34 & 2.855 & 1.04 \\
\hline CRISIS & 0.108 & 1.19 & 0.041 & 0.51 & 0.035 & 0.48 \\
\hline $\mathrm{C}$ & -0.092 & 0.08 & $-0.122 *$ & -1.71 & -0.094 & -1.42 \\
\hline Observations & 70 & & 70 & & 70 & \\
\hline Sargan, AR(2) & 0.00 & 0.14 & 0.15 & 0.14 & 0.24 & 0.18 \\
\hline Two Periods Model & coeff. & z-stat & coeff. & z-stat & coeff. & z-stat \\
\hline CPI (lags) & -0.005 & -0.28 & 0.008 & 0.46 & 0.011 & 0.71 \\
\hline PEG 94-97 & -0.015 & -0.06 & & & & \\
\hline PEG 98-02 & 0.138 & 0.74 & & & & \\
\hline IMD 94-97 & -0.132 & -1.07 & & & & \\
\hline IMD 98-02 & -0.062 & -0.58 & & & & \\
\hline EUVOL 94-97 & & & $2.231 * *$ & 2.52 & & \\
\hline EUVOL 98-02 & & & 1.513 & 0.51 & & \\
\hline NOMEFF 94-97 & & & & & $4.814 * * *$ & 4.58 \\
\hline NOMEFF 98-02 & & & & & 4.365 & 1.20 \\
\hline TARGET & -0.064 & -0.63 & -0.028 & -0.30 & -0.028 & -0.33 \\
\hline GDP & $-1.037 * *$ & -2.57 & $-0.669 *$ & -1.67 & -0.211 & -0.57 \\
\hline MON & $1.156^{* * *}$ & 40.71 & $0.997 * * *$ & 15.11 & $0.820 * * *$ & 10.69 \\
\hline GDPEU & 1.728 & 0.52 & 4.010 & 1.34 & 2.917 & 0.99 \\
\hline CRISIS & 0.050 & 0.46 & 0.053 & 0.56 & 0.038 & 0.45 \\
\hline $\mathrm{C}$ & -0.089 & -1.14 & $-0.122 *$ & -1.70 & -0.094 & -1.34 \\
\hline Observations & 70 & & 70 & & 70 & \\
\hline Sargan, AR(2) & 0.01 & 0.12 & 0.11 & 0.16 & 0.19 & 0.21 \\
\hline
\end{tabular}

Source: IMF: IFS. Yearly data. * significant at the $10 \%$ level. ${ }^{* *}$ significant at the $5 \%$ level. *** significant at the $1 \%$ level. Sargan corresponds to Sargan test of over-identifying restrictions ( $\mathrm{p}$-value). $\operatorname{AR}(2)=$ Arellano-Bond test that average covariance in residuals of order 2 is zero ( $p$-value). 
Table 8: Arelleano-Bond Panel Estimation for Inflation - Bulgaria \& Romania excluded

\begin{tabular}{|c|c|c|c|c|c|c|}
\hline \multirow{2}{*}{$\begin{array}{l}8 \text { Countries } \\
\text { One Period Model }\end{array}$} & \multicolumn{2}{|c|}{ de jure } & \multicolumn{2}{|c|}{ de facto I } & \multicolumn{2}{|c|}{ de facto II } \\
\hline & coeff. & z-stat & coeff. & z-stat & coeff. & z-stat \\
\hline CPI (lags) & $0.619 * * *$ & 9.83 & $0.615 * * *$ & 11.14 & $0.614 * * *$ & 11.12 \\
\hline PEG & dropped & dropped & & & & \\
\hline IMD & $0.005^{*}$ & 0.26 & & & & \\
\hline EUVOL & & & 0.183 & 0.34 & & \\
\hline NOMEFF & & & & & -0.163 & -0.19 \\
\hline TARGET & -0.017 & -1.17 & -0.013 & -0.95 & -0.156 & -1.09 \\
\hline GDP & -0.032 & -0.40 & -0.048 & -0.65 & -0.033 & -0.46 \\
\hline MON & $-0.061 *$ & -1.83 & $-0.060 *$ & -1.86 & $-0.060^{*}$ & -1.85 \\
\hline GDPEU & 0.948 & 1.67 & $0.944^{*}$ & 1.77 & $0.954^{*}$ & 1.68 \\
\hline CRISIS & -0.002 & -0.15 & -0.004 & -0.26 & -0.001 & -0.08 \\
\hline $\mathrm{C}$ & $-0.025 *$ & -1.88 & $-0.025 * *$ & -1.96 & $-0.026 *$ & -1.90 \\
\hline Observations & 56 & & 56 & & 56 & \\
\hline Sargan, AR(2) & 0.32 & 0.30 & 0.17 & 0.26 & 0.28 & 0.28 \\
\hline Two Periods Model & coeff. & z-stat & coeff. & z-stat & coeff. & z-stat \\
\hline CPI (lags) & $0.679 * * *$ & 8.81 & $0.596 * * *$ & 10.77 & $0.614 * * *$ & 10.64 \\
\hline PEG 94-97 & -0.019 & -0.54 & & & & \\
\hline PEG 98-02 & dropped & dropped & & & & \\
\hline IMD 94-97 & 0.031 & 1.25 & & & & \\
\hline IMD 98-02 & -0.002 & -0.11 & & & & \\
\hline EUVOL 94-97 & & & $1.852 * *$ & 2.37 & & \\
\hline EUVOL 98-02 & & & -0.249 & -0.43 & & \\
\hline NOMEFF 94-97 & & & & & 1.453 & 1.07 \\
\hline NOMEFF 98-02 & & & & & -0.110 & -0.13 \\
\hline TARGET & -0.007 & -0.47 & -0.005 & -0.35 & -0.104 & -0.68 \\
\hline GDP & -0.031 & 0.08 & -0.052 & -0.70 & -0.040 & -0.51 \\
\hline MON & $-0.080 * *$ & -2.27 & $-0.072 * *$ & -2.21 & $-0.062 *$ & -1.83 \\
\hline GDPEU & $1.084 *$ & 1.87 & $0.979 *$ & 1.81 & $0.958^{*}$ & 1.61 \\
\hline CRISIS & 0.007 & 0.30 & 0.016 & 1.02 & 0.153 & 0.86 \\
\hline $\mathrm{C}$ & $-0.026 * *$ & -1.92 & $-0.025 *$ & -1.92 & $-0.024 *$ & -1.76 \\
\hline Observations & 56 & & 56 & & 56 & \\
\hline Sargan, AR(2) & 0.70 & 0.98 & 0.39 & 0.15 & 0.36 & 0.16 \\
\hline
\end{tabular}

Source: IMF: IFS. Yearly data. * significant at the $10 \%$ level. ${ }^{* *}$ significant at the $5 \%$ level. $* * *$ significant at the $1 \%$ level. Sargan = Sargan test of over-identifying restrictions ( $p$-value). $\operatorname{AR}(2)=$ Arellano-Bond test that average covariance in residuals of order 2 is zero (p-value). 
Table 9: Panel GLS Estimation for Growth - All Countries

\begin{tabular}{|c|c|c|c|c|c|c|}
\hline \multirow{2}{*}{$\begin{array}{l}10 \text { countries } \\
\text { One Period Model }\end{array}$} & \multicolumn{2}{|c|}{ de jure } & \multicolumn{2}{|c|}{ de facto I } & \multicolumn{2}{|c|}{ de facto II } \\
\hline & coeff. & t-stat & coeff. & t-stat & coeff. & t-stat \\
\hline $\mathrm{C}$ & 0.020 & 1.53 & $0.035 * * *$ & 6.04 & $0.037 * * *$ & 6.19 \\
\hline PEG & -0.004 & -0.34 & & & & \\
\hline IMD & $0.0190 * * *$ & 4.72 & & & & \\
\hline EUVOL & & & $-0.174 * * *$ & -30.37 & & \\
\hline NOMEFF & & & & & $-0.173 * * *$ & -27.70 \\
\hline INVGDP & 0.003 & 0.06 & 0.002 & 0.08 & 0.002 & 0.06 \\
\hline EXPGR & $0.056 * *$ & 2.38 & $0.058 * * *$ & 3.42 & $0.054 * * *$ & 3.22 \\
\hline DEF & $0.434 * * *$ & 4.38 & $0.298 * * *$ & 9.16 & $0.311 * * *$ & 9.53 \\
\hline CAPGDP & $0.150 * * *$ & 3.35 & $0.164 * * *$ & 4.43 & $0.160 * * *$ & 4.38 \\
\hline TARGET & 0.005 & 1.11 & -0.001 & -0.29 & -0.001 & -0.33 \\
\hline CRISIS & $-0.013 * *$ & -2.07 & $-0.010 *$ & -1.73 & $-0.011 *$ & -1.88 \\
\hline GDPEU & $0.349 * * *$ & 2.92 & 0.132 & 1.37 & $0.154 *$ & 1.63 \\
\hline Observations, $\mathrm{R}^{2}$ adj. & 83 & 0.36 & 83 & 0.60 & 83 & 0.61 \\
\hline Two Periods Model & coeff. & t-stat & coeff. & t-stat & coeff. & t-stat \\
\hline PEG 94-97 & $-0.057 *$ & -1.92 & & & & \\
\hline PEG 98-02 & -0.004 & -0.44 & & & & \\
\hline IMD 94-97 & $0.012 * *$ & 2.28 & & & & \\
\hline IMD 98-02 & -0.001 & -0.09 & & & & \\
\hline EUVOL 94-97 & & & $-0.143 * * *$ & -24.22 & & \\
\hline EUVOL 98-02 & & & $-1.187 * * *$ & -7.23 & & \\
\hline NOMEFF 94-97 & & & & & $-0.155 * * *$ & -33.17 \\
\hline NOMEFF 98-02 & & & & & $-0.762 * * *$ & -7.98 \\
\hline INVGDP & $0.348 * * *$ & 6.49 & $0.332 * * *$ & 8.86 & $0.270 * * *$ & 7.60 \\
\hline EXPGR & $0.088 * * *$ & 7.27 & $0.064 * * *$ & 5.49 & $0.061 * * *$ & 5.19 \\
\hline DEF & $0.443 * * *$ & 5.40 & $0.344 * * *$ & 12.67 & $0.384 * * *$ & 17.74 \\
\hline CAPGDP & $0.115 * * *$ & 3.97 & $0.091 * * *$ & 3.90 & $0.088 * * *$ & 4.14 \\
\hline TARGET & $0.016^{* * *}$ & 4.92 & $0.016^{* * *}$ & 4.55 & $0.013 * * *$ & 4.64 \\
\hline CRISIS & $-0.021 * * *$ & -5.26 & $-0.008 *$ & -1.87 & $-0.013 * * *$ & -3.64 \\
\hline GDPEU & $0.305 * * *$ & 3.23 & $0.323 * * *$ & 3.48 & $0.411 * * *$ & 4.93 \\
\hline \multicolumn{7}{|l|}{ Fixed Effects } \\
\hline BUL & -0.034 & & -0.024 & & -0.008 & \\
\hline CZE & -0.104 & & -0.085 & & -0.065 & \\
\hline EST & -0.050 & & -0.069 & & -0.047 & \\
\hline HUN & -0.048 & & -0.033 & & -0.017 & \\
\hline LAT & -0.037 & & -0.016 & & -0.008 & \\
\hline LIT & 0.045 & & 0.041 & & 0.045 & \\
\hline POL & -0.038 & & -0.008 & & -0.001 & \\
\hline ROM & -0.057 & & -0.027 & & -0.023 & \\
\hline SLK & -0.077 & & -0.058 & & -0.039 & \\
\hline SLO & -0.050 & & -0.042 & & -0.025 & \\
\hline Observations, $\mathrm{R}^{2}$ adj. & 83 & 0.57 & 83 & 0.75 & 83 & 0.70 \\
\hline
\end{tabular}

Source: IMF: IFS. Yearly data. ${ }^{*}$ significant at the $10 \%$ level. $* *$ significant at the $5 \%$ level. $* * *$ significant at the $1 \%$ level. White heteroskedasticity-consistent standard errors and covariance. 
Table 10: Panel GLS Estimation for Growth - All Countries excl. BUL, ROM

\begin{tabular}{lrrrrrr}
\hline 8 countries & \multicolumn{2}{c}{ de jure } & \multicolumn{2}{c}{ de facto I } & \multicolumn{2}{c}{ de facto II } \\
One Period Model & \multicolumn{1}{c}{ coeff. } & \multicolumn{1}{c}{ t-stat } & \multicolumn{1}{c}{ coeff. } & t-stat & \multicolumn{1}{c}{ coeff. } & t-stat \\
\hline C & $0.066^{* * *}$ & 8.99 & $0.059 * * *$ & 6.945302 & $0.073 * * *$ & 8.85 \\
PEG & 0.008 & 0.55 & & & & \\
IMD & $0.014 * * *$ & 3.47 & & & & \\
EUVOL & & & 0.377 & 1.36 & & \\
NOMEFF & & & & & $-1.04 * * *$ & -2.92 \\
INVGDP & $-0.149 * * *$ & -4.11 & $-0.105^{* *}$ & -2.43 & $-0.100^{* * *}$ & -2.74 \\
EXPGR & 0.001 & 0.09 & 0.014 & 0.63 & 0.020 & 0.87 \\
DEF & $0.320^{* *}$ & 2.15 & $0.306^{* * *}$ & 2.85 & 0.103 & 1.03 \\
CAPGDP & $0.159 * * *$ & 3.22 & $0.186 * * *$ & 3.62 & $0.170 * * *$ & 3.47 \\
TARGET & -0.002 & -0.50 & -0.007 & -1.42 & -0.004 & -0.97 \\
CRISIS & -0.004 & -0.89 & -0.006 & -1.07 & -0.003 & -0.69 \\
GDPEU & $0.330^{* *}$ & 2.42 & $0.237 *$ & 1.68 & $0.340 * *$ & 2.54 \\
\hline Observations, $\mathrm{R}^{2}$ adj. & 65 & 0.28 & 65 & 0.33 & 65 & 0.29 \\
\hline
\end{tabular}

\begin{tabular}{|c|c|c|c|c|}
\hline \multicolumn{5}{|l|}{ Two Periods Model } \\
\hline PEG 94-97 & & & & \\
\hline PEG 98-02 & & & & \\
\hline IMD 94-97 & & & & \\
\hline IMD 98-02 & & & & \\
\hline EUVOL 94-97 & 0.507 & 0.89 & & \\
\hline EUVOL 98-02 & $-0.885 * * *$ & -3.39 & & \\
\hline NOMEFF 94-97 & & & $-0.465^{*}$ & -1.71 \\
\hline NOMEFF 98-02 & & & $-1.10 * * *$ & -5.84 \\
\hline INVGDP & $0.380 * * *$ & 4.03 & $0.261 * * *$ & 4.17 \\
\hline EXPGR & $0.050 *$ & 1.84 & $0.044 * *$ & 2.03 \\
\hline DEF & $0.631 * * *$ & 3.45 & $0.451 * * *$ & 3.16 \\
\hline CAPGDP & 0.067 & 1.61 & $0.072 * *$ & 2.18 \\
\hline TARGET & $0.021 * *$ & 2.43 & $0.013 * * *$ & 2.62 \\
\hline CRISIS & $-0.017 * * *$ & -3.02 & $-0.014 * * *$ & -2.62 \\
\hline GDPEU & $0.541 * * *$ & 3.54 & $0.502 * * *$ & 4.09 \\
\hline
\end{tabular}

\section{Fixed Effects}

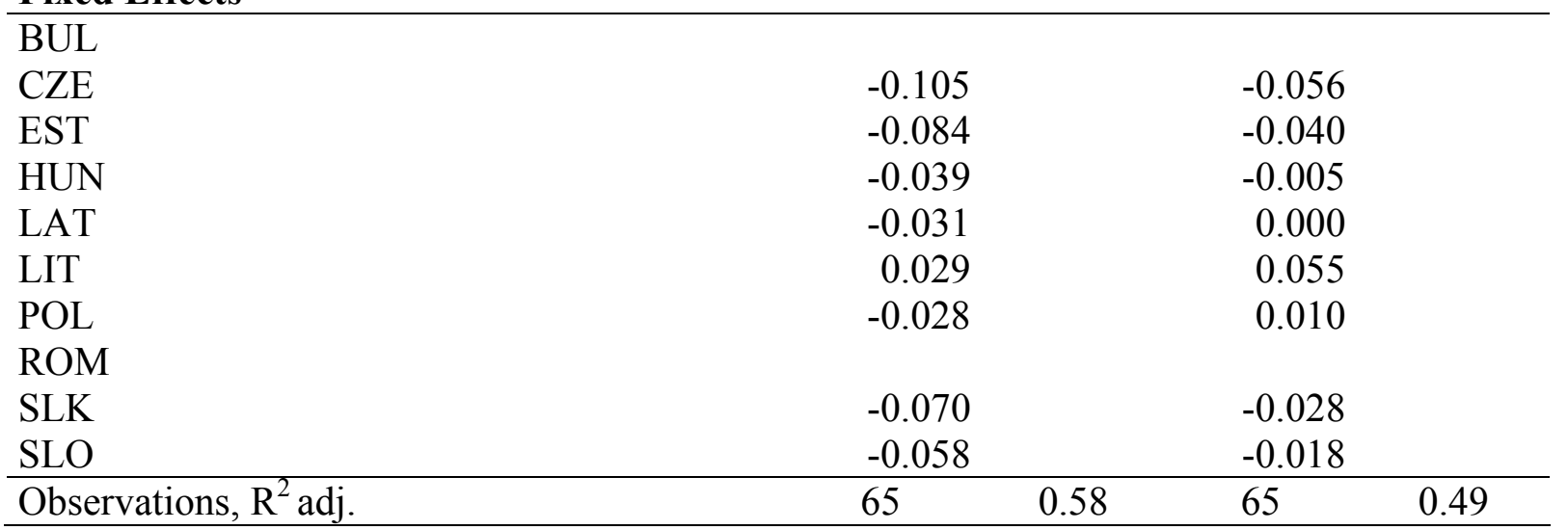

Source: IMF: IFS. Yearly data. * significant at the $10 \%$ level. $* *$ significant at the $5 \%$ level. $* * *$ significant at the $1 \%$ level. White heteroskedasticity-consistent standard errors and covariance. 


\section{Data}

Macroeconomic data on exchange rate rates, CPI inflation, WPI inflation, foreign reserves, monetary base, money, nominal interest rates, dollar exports, foreign reserves and short-term capital flows are monthly data from IMF International Financial Statistics. Real GDP are quarterly data from the same source. Volatilities are computed as yearly standard deviations of month-to-month percentage changes. By calculating yearly standard deviations we loose a considerable number of observations in comparison to quarterly or monthly data, but we avoid possible bias caused by computing moving standard deviations of overlapping monthly or quarterly percentage change rates.

Openness is calculated as the nominal trade (exports plus imports) divided by nominal GDP (yearly values). A dummy for inflation targeting (TARGET) is computed according to the official statements about the adoption of inflation targeting frameworks by the respective central banks. The dummy for central bank independence (INDEP) is constructed based on the day when the respective central banks became officially independent. An alternative measure of central bank independence is taken from Cuikerman, Miller and Neyapti (2002). The dummy for the speculative crisis which hit Central and Eastern Europe in the aftermath of the Asian crisis is introduced for the year 1998 for the countries affected by speculative attacks. 


\section{CESifo Working Paper Series}

(for full list see www.cesifo.de)

1117 Gianmarco I.P. Ottaviano and Giovanni Peri, The Economic Value of Cultural Diversity: Evidence from US Cities, January 2004

1118 Thorvaldur Gylfason, Monetary and Fiscal Management, Finance, and Growth, January 2004

1119 Hans Degryse and Steven Ongena, The Impact of Competition on Bank Orientation and Specialization, January 2004

1120 Piotr Wdowinski, Determinants of Country Beta Risk in Poland, January 2004

1121 Margarita Katsimi and Thomas Moutos, Inequality and Redistribution via the Public Provision of Private Goods, January 2004

1122 Martin Peitz and Patrick Waelbroeck, The Effect of Internet Piracy on CD Sales: CrossSection Evidence, January 2004

1123 Ansgar Belke and Friedrich Schneider, Privatization in Austria: Some Theoretical Reasons and First Results About the Privatization Proceeds, January 2004

1124 Chang Woon Nam and Doina Maria Radulescu, Does Debt Maturity Matter for Investment Decisions?, February 2004

1125 Tomer Blumkin and Efraim Sadka, Minimum Wage with Optimal Income Taxation, February 2004

1126 David Parker, The UK's Privatisation Experiment: The Passage of Time Permits a Sober Assessment, February 2004

1127 Henrik Christoffersen and Martin Paldam, Privatization in Denmark, 1980-2002, February 2004

1128 Gregory S. Amacher, Erkki Koskela and Markku Ollikainen, Deforestation, Production Intensity and Land Use under Insecure Property Rights, February 2004

1129 Yin-Wong Cheung, Javier Gardeazabal, and Jesús Vázquez, Exchange Rate Dynamics: Where is the Saddle Path?, February 2004

1130 Alberto Alesina and Guido Tabellini, Bureaucrats or Politicians?, February 2004

1131 Gregory S. Amacher, Erkki Koskela, and Markku Ollikainen, Socially Optimal Royalty Design and Illegal Logging under Alternative Penalty Schemes, February 2004

1132 David M. Newbery, Privatising Network Industries, February 2004 
1133 Charles Yuji Horioka, The Stagnation of Household Consumption in Japan, February 2004

1134 Eiji Fujii, Exchange Rate Pass-Through in the Deflationary Japan: How Effective is the Yen's Depreciation for Fighting Deflation?, February 2004

1135 Mark M. Spiegel and Nobuyoshi Yamori, Determinants of Voluntary Bank Disclosure: Evidence from Japanese Shinkin Banks, Febrary 2004

1136 Robert Dekle and Kenneth Kletzer, Deposit Insurance, Regulatory Forbearance and Economic Growth: Implications for the Japanese Banking Crisis, February 2004

1137 Takatoshi Ito and Kimie Harada, Bank Fragility in Japan, 1995-2003, February 2004

1138 Kunio Okina and Shigenori Shiratsuka, Policy Duration Effect under Zero Interest Rates: An Application of Wavelet Analysis, February 2004

1139 Francine D. Blau and Lawrence M. Kahn, Do Cognitive Test Scores Explain Higher U.S. Wage Inequality?, February 2004

1140 Michael Rauscher, Economic Growth and Tax-Competing Leviathans, February 2004

1141 Ernst Fehr and Jean-Robert Tyran, Money Illusion and Coordination Failure, February 2004

1142 Ingo Vogelsang, Network Utilities in the U.S. - Sector Reforms without Privatization, March 2004

1143 Marc-Andreas Muendler, Estimating Production Functions When Productivity Change is Endogenous, March 2004

1144 Sascha O. Becker, Samuel Bentolila, Ana Fernandes, and Andrea Ichino, Job Insecurity and Children's Emancipation, March 2004

1145 Pascalis Raimondos-Møller and Alan D. Woodland, Non-Preferential Trading Clubs, March 2004

1146 Robert Fenge and Matthias Wrede, EU Regional Policy: Vertical Fiscal Externalities and Matching Grants, March 2004

1147 Chi-Yung Ng and John Whalley, Geographical Extension of Free Trade Zones as Trade Liberalization: A Numerical Simulation Approach, March 2004

1148 Marc-Andreas Muendler, Trade, Technology, and Productivity: A Study of Brazilian Manufacturers, 1986-1998, March 2004

1149 Eugene Beaulieu, Vivek H. Dehejia, and Hazrat-Omar Zakhilwal, International Trade, Labour Turnover, and the Wage Premium: Testing the Bhagwati-Dehejia Hypothesis for Canada, March 2004 
1150 Giorgio Brunello and Francesca Gambarotto, Agglomeration Effects on EmployerProvided Training: Evidence from the UK, March 2004

1151 S. Brock Blomberg, Gregory D. Hess, and Athanasios Orphanides, The Macroeconomic Consequences of Terrorism, March 2004

1152 Bodo Sturm and Joachim Weimann, Unilateral Emissions Abatement: An Experiment, March 2004

1153 Wolfgang Ochel, Welfare-to-Work Experiences with Specific Work-First Programmes in Selected Countries, March 2004

1154 Jan K. Brueckner and Eric Pels, European Airline Mergers, Alliance Consolidation, and Consumer Welfare, March 2004

1155 Aaron Tornell, Frank Westermann, and Lorenza Martínez, NAFTA and Mexico's Economic Performance, March 2004

1156 George Economides, Sarantis Kalyvitis, and Apostolis Philippopoulos, Do Foreign Aid Transfers Distort Incentives and Hurt Growth? Theory and Evidence from 75 Aidrecipient Countries, March 2004

1157 Robert Fenge and Volker Meier, Are Family Allowances and Fertility-related pensions Siamese Twins?, March 2004

1158 Bruno S. Frey, Simon Luechinger, and Alois Stutzer, Valuing Public Goods: The Life Satisfation Approach, March 2004

1159 Jerome L. Stein and Guay C. Lim, Asian Crises: Theory, Evidence, Warning-Signals, March 2004

1160 Romain Ranciere, Aaron Tornell, and Frank Westermann, Crises and Growth: A ReEvaluation, March 2004

1161 Assaf Razin and Efraim Sadka, Transparency, Specialization and FDI, March 2004

1162 Ludger Woessmann, How Equal Are Educational Opportunities? Family Background and Student Achievement in Europe and the United States, March 2004

1163 B.M.S. van Praag and Barbara E. Baarsma, Using Happiness Surveys to Value Intangibles: The Case of Airport Noise, March 2004

1164 Aaron Tornell, Frank Westermann, and Lorenza Martínez, The Positive Link Between Financial Liberalization, Growth, and Crises, March 2004

1165 Helge Berger and Carsten Hefeker, One Country, One Vote? Labor Market Structure and Voting Rights in the ECB, March 2004

1166 Clemens Fuest and Martin Kolmar, A Theory of User-Fee Competition, March 2004 
1167 Friedrich Schneider and Robert Klinglmair, Shadow Economies around the World: What Do We Know?, April 2004

1168 Horst Raff and Nicolas Schmitt, Exclusive Dealing and Common Agency in International Markets, April 2004

1169 M. Hashem Pesaran and Allan Timmermann, Real Time Econometrics, April 2004

1170 Sean D. Barrett, Privatisation in Ireland, April 2004

1171 V. Anton Muscatelli, Patrizio Tirelli and Carmine Trecroci, Can Fiscal Policy Help Macroeconomic Stabilisation? Evidence from a New Keynesian Model with Liquidity Constraints, April 2004

1172 Bernd Huber and Marco Runkel, Tax Competition, Excludable Public Goods and User Charges, April 2004

1173 John McMillan and Pablo Zoido, How to Subvert Democracy: Montesinos in Peru, April 2004

1174 Theo Eicher and Jong Woo Kang, Trade, Foreign Direct Investment or Acquisition: Optimal Entry Modes for Multinationals, April 2004

1175 Chang Woon Nam and Doina Maria Radulescu, Types of Tax Concessions for Attracting Foreign Direct Investment in Free Economic Zones, April 2004

1176 M. Hashem Pesaran and Andreas Pick, Econometric Issues in the Analysis of Contagion, April 2004

1177 Steinar Holden and Fredrik Wulfsberg, Downward Nominal Wage Rigidity in Europe, April 2004

1178 Stefan Lachenmaier and Ludger Woessmann, Does Innovation Cause Exports? Evidence from Exogenous Innovation Impulses and Obstacles, April 2004

1179 Thiess Buettner and Johannes Rincke, Labor Market Effects of Economic Integration The Impact of Re-Unification in German Border Regions, April 2004

1180 Marko Koethenbuerger, Leviathans, Federal Transfers, and the Cartelization Hypothesis, April 2004

1181 Michael Hoel, Tor Iversen, Tore Nilssen, and Jon Vislie, Genetic Testing and Repulsion from Chance, April 2004

1182 Paul De Grauwe and Gunther Schnabl, Exchange Rate Regimes and Macroeconomic Stability in Central and Eastern Europe, April 2004 